\title{
Sex differences in resource utilization by the peacock blenny
}

\author{
E.J. G onçalves and V. C. A lmada \\ U nidade de I nvestigação em E co-E tologia, Instituto Superior de P sicologia A plicada, \\ R ua J ardim do Tabaco, 44, P-1100 L isboa, P ortugal
}

(Received 12 February 1997, Accepted 28 A pril 1997)

\begin{abstract}
This paper presents data on the seasonal variation of gonadosomatic, hepatosomatic and feeding indices in nesting males, females and female-like males of the blenniid fish Salaria pavo. Eviscerated condition factors, female fecundity and feeding rates are also presented. The results are consistent with the hypothesis that females maximize their feeding rates during reproduction, converting food into eggs through repeated spawning. N esting males feed at a very low rate during the breeding season. It is argued that one major component of the reproductive costs in these males is the reduction of feeding opportunities. F emale-like males present lower reproductive costs, which probably reflects the compromise between fertilizing some eggs and growing.

(C) 1997 The Fisheries Society of the British I sles
\end{abstract}

K ey words: Salaria pavo; Blenniidae; reproductive costs; parental care; body condition; alternative reproductive tactics.

\section{INTRODUCTION}

The costs of parental care in teleost fishes, and the ways in which males and females invest resources in reproduction have been studied in several fish species (e.g. M iller, 1984; Sargent \& G ross, 1986; A Imada, 1990). At low to moderate latitudes, which allow a long breeding season, it is found that females spawn repeatedly and, in some cases, produce a total weight of eggs that may exceed their own weight (Wootton, 1973; Barlow, 1984; M iller, 1984). In these situations, it is expected that, for females, the breeding season is a period of maximal feeding, in which food is steadily converted into eggs. This ability of females to increase fecundity, combined with male territoriality and the ability of males to care for an increasing number of eggs with little additional cost, has been considered by several authors as one of the factors that has contributed to the repeated evolution of male parental care in bony fishes (Blumer, 1979; Baylis, 1981; G itleman, 1981; Barlow, 1984; A Imada, 1990). F or males that care and guard the eggs, one of the likely features of male reproductive investment is a reduction of feeding opportunities during the breeding season (e.g. Q asim, 1957; M iller, 1984; Sargent \& G ross, 1986; Santos \& A Imada, 1988; Chellappa et al., 1989; A Imada et al., 1992; Santos, 1992; Almada \& Santos, 1995; Smith \& Wootton, 1995; Santos et al., 1996).

Salaria pavo ( $\mathrm{R}$ isso, 1810 ) is ideal to test this hypothesis. Like all other blenniids, the male guards and cares for the eggs, and there is no defined parental cycle. The male may guard the nest for many weeks, and a succession of females may spawn in the same nest, increasing significantly the duration of continuous parental care. In addition, in the population studied here, the nests were densely aggregated and the nesting males minimized their excursions from the nest and 
occupied breeding territories that were virtually limited to the nest hole, therefore with no food resources. There was an excess of mature males that could not establish nests and nesting males were significantly larger than non-nesting males. The smaller non-nesting males were almost identical to females both in morphology and behaviour and acted as sneakers (female-like males), while the larger ones acted as floaters and tried to take over the nests of parental males. Several aspects of the biology and behaviour of this population have been described in previous papers (A Imada et al., 1994, 1995; G onçalves et al., 1996). In this paper, data is presented on the patterns of resource utilization by male and female $S$. pavo.

\section{MATERIALS AND METHODS}

The population studied was found in a lagoon environment at $\mathrm{R}$ ia Formosa, southern Portugal $\left(36^{\circ} 59^{\prime} \mathrm{N}, 7^{\circ} 51^{\prime} \mathrm{W}\right.$ ), where the only available cavities were bricks used by clam culturists to delimit their fields. The boundaries of adjacent clam cultures were delimited by several kinds of hard debris (bricks, tiles, stones) that formed ridges $10-20 \mathrm{~cm}$ high. All the nests found occurred intertidally along these ridges. When the tide ebbed, nesting males stayed inside the bricks, while most females and non-nesting males moved to the channels and adjacent eelgrass beds.

F ish samples were collected during the breeding season of 1988 (A ugust), 1990 (M ay), 1991 (J uly), 1993 (A pril, September) and 1994 (J anuary). F ish were caught with the help of a hand-net and killed with an overdose of quinaldine. The following measurements were taken: body weight (W ), eviscerated weight $\left(W_{e}\right)$, gonad weight $\left(W_{g}\right)$, liver weight $\left(W_{1}\right)$, gut weight $\left(W_{a}\right)$, and standard length $(L)$. The guts were inspected for the amount of food present and were classified as: empty or with few items, and partially or completely full. The presence of blenniid eggs was also recorded. All samples were kept to a minimum and were collected during several years, since this species has been listed as vulnerable in Portugal (ICN, 1993), and this is the only stable population known in the country. Indeed, the biological material used in this study was not specifically collected for this purpose and was available as a by-product of a broader study on the biology of S. pavo, aimed to acquire information needed for the conservation of this species. Additional measurements were taken from live fish that were returned immediately to their habitat. The following indices were calculated:

gonadosomatic index, $\mathrm{I}_{\mathrm{G}}=100 \mathrm{~W} / \mathrm{W}$;

hepatosomatic index, $I_{H}=100 \mathrm{~W}_{\mathrm{I}} / \mathrm{W}$;

feeding index, $I_{F}=100 \mathrm{~W}_{\mathrm{a}} / \mathrm{W}$;

eviscerated condition factor, $K_{e}=1000 W_{e} / L^{3}$.

L ow tide field inspections were made during the 1988 breeding season. A total of $40 \mathrm{~m}$ of ridges was selected for regular inspection. All nesting males found were captured with the help of a hand-net, measured to the nearest $\mathrm{mm}$, weighed and marked. M arking was performed by fin clipping. In each monthly visit, all caught individuals were inspected and if they were already marked, their identity was recorded.

F ocal behavioural observations were conducted by snorkelling on 65 nesting males and 16 females in the breeding season of 1994 (total observation time= $35 \mathrm{~h} 21 \mathrm{~min}$ ). In each observation, the number of feeding acts performed by the fish, and the net distance moved (the linear distance from the starting point to the finishing position) were recorded.

One group of fishes (four nesting males, one floater male and five females) was kept in a $78 \times 40 \times 35-\mathrm{cm}$ aquarium with gravel and boulders to provide shelter. Photoperiod was kept constant (LD $16: 8$ ) by a fluorescent light (18 W), and temperature varied from 27 to $28^{\circ} \mathrm{C}$. They were fed with common cockles (Cerastoderma spp.) and live marine 


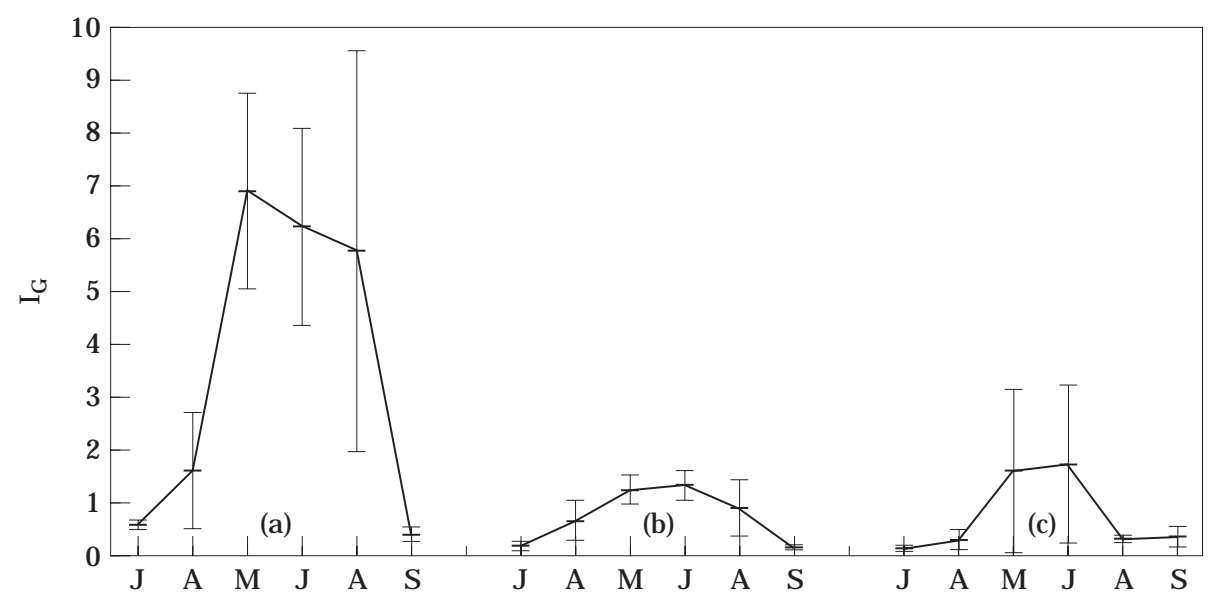

F IG. 1. Variation of mean ( \pm S.D.) gonadosomatic indices $\left(I_{G}\right)$ in (a) females, (b) nesting males, and (c) female-like males throughout the year.

invertebrates. G lass parallelepiped nests $(3 \times 3 \times 15 \mathrm{~cm})$ with narrow apertures were constructed. Each nest was wrapped with a black plastic sheet. The total area covered by the egg layer was measured by removing the black plastic sheet and applying a 1-cm ${ }^{2}$ grid, counting the number of squares occupied by the spawn. Also, the density of eggs was determined to estimate the total number of eggs present in each nest. The egg masses were followed during 30 days.

Statistical analysis of the data was performed using Statistica for W indows 4.5 and the simulation statistical program Actus (Estabrook \& Estabrook, 1989) designed for the analysis of contingency tables. This program uses random numbers to simulate 1000 tables, each with the same row and column total of the original table. Each simulated table is compared with the original data table. Values smaller than 50 are one-tailed significant $(P<0.05)$. The significance of $\chi^{2}$ is assessed by the number of times out of 1000 that the value of $\chi^{2}$ for the simulated tables is equal to or greater than that for the original table (Estabrook \& Estabrook, 1989).

D ata transformations were applied to comply with the assumptions of A N OV A (Sokal $\&$ R ohlf, 1981), and non-parametric tests were used when those assumptions could not be satisfied.

\section{RESULTS}

\section{GONADOSOM ATIC INDEX}

The mean ( \pm S.D.) female gonadosomatic indices $\left(I_{G}\right)$ reached a peak in $M$ ay $(6 \cdot 93 \pm 1 \cdot 84$, range $=5 \cdot 16-9 \cdot 30, n=6)$, while the nesting males and female like males reached the highest $I_{G}$ values in J uly $(1 \cdot 36 \pm 0 \cdot 29$, range $=0 \cdot 90-1 \cdot 75, n=10$; and $1.73 \pm 1 \cdot 49$, range $=0 \cdot 17-3 \cdot 59, n=9$, respectively) ( $F i g .1)$. The $I_{G}$ values were in accordance with the breeding season previously described for this population: end of A pril to September (A Imada et al., 1994). In female-like males $I_{G}$ values were high for a shorter period ( $M$ ay-J uly).

\section{HEPATOSOMATIC INDEX}

The highest values of the hepatosomatic index $\left(\mathrm{I}_{H}\right)$ were reached prior to reproduction (females: $3.88 \pm 1 \cdot 07$, range $=2 \cdot 28-5 \cdot 92, n=8$, in April; nesting males: $3.44 \pm 1.09$, range $=1.06-4.45, n=8$, in A pril; female-like males: $3 \cdot 32 \pm 0 \cdot 64$, range $=2 \cdot 30-4 \cdot 30, n=8$, in J anuary) (Fig. 2). There was a highly 


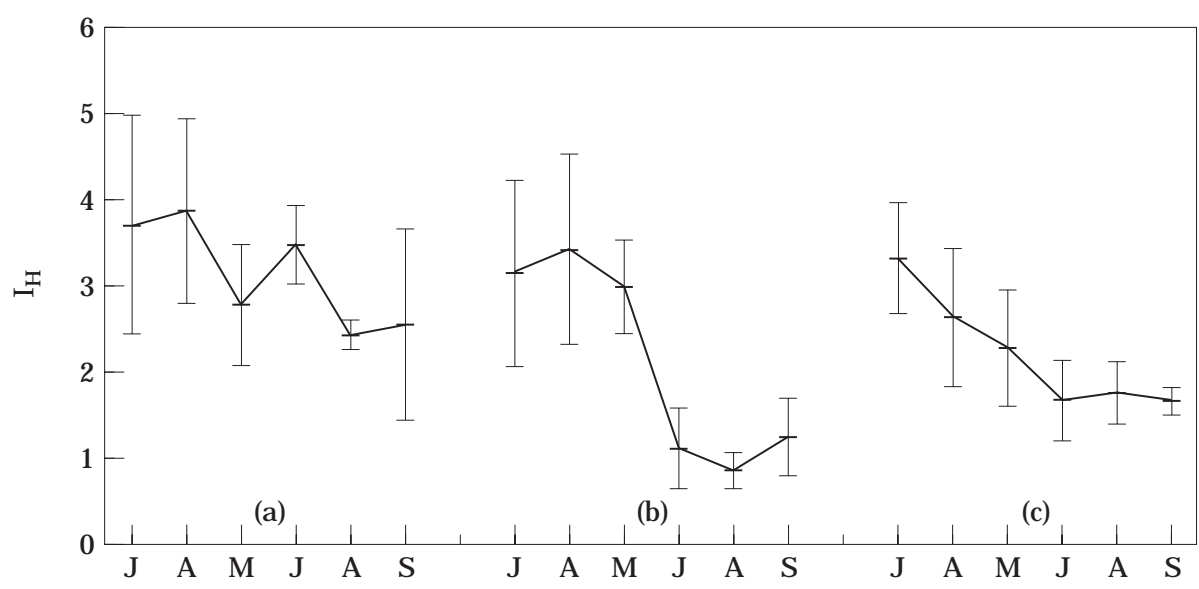

F IG. 2. Variation of mean ( \pm S.D.) hepatosomatic indices $\left(I_{H}\right)$ in (a) females, (b) nesting males, and (c) female-like males throughout the year.

significant difference both between months (K ruskal-Wallis test: $H(5, n=135)$ $=51.36, P<0.001)$ and sexual categories (K ruskal-Wallis test: $H \quad(2, n=135)$ $=25.99, \mathrm{P}<0.001) . \mathrm{I}_{H}$ values in J uly, A ugust and September were significantly lower $(P<0.001)$ than January and A pril (D unn's test: Jan/J ul, $Q=4.37$; J an/ Aug, $Q=4.49 ; \quad J$ an/Sep, $Q=5.16 ;$ and $A$ pr/J ul, $Q=4.02 ; A$ pr/Aug, $Q=4.20$; A pr/Sep, $Q=4.78)$. In females overall $I_{H}$ values were significantly higher $(P<0.001)$ than in both types of males (D unn's test: females/nesting males, $\mathrm{Q}=4 \cdot 89$; females/female-like males, $\mathrm{Q}=3.65$ ).

In nesting males $I_{H}$ declined sharply from $M$ ay to $J$ uly and recovered only after the breeding season (between October and J anuary). F emales showed some variation in $\mathrm{I}_{H}$, but the values remained high during the breeding season. Female-like males showed an intermediate pattern with a smoother decline as breeding progressed.

\section{EVISCERATED CONDITION FACTOR AND WEIGHTS}

The highest values of the eviscerated condition factor $\left(\mathrm{K}_{\mathrm{e}}\right)$ were reached prior to reproduction (A pril) by females $(13 \cdot 00 \pm 0.98$, range $=11 \cdot 73-14 \cdot 17, n=8)$ and nesting males $(15 \cdot 69 \pm 1 \cdot 37$, range $=13 \cdot 78-15 \cdot 06, n=8)$. Female-like males reached their highest $\mathrm{K}_{\mathrm{e}}$ values in September $(13.06 \pm 0.91$, range $=12 \cdot 37-14 \cdot 97$, $n=8$ ) (Fig. 3). There was a highly significant difference both between months and sexual categories (Table I). In females, $\mathrm{K}_{\mathrm{e}}$ dropped significantly from A pril to J uly (Tukey H SD test: $P<0.01$ ) and recovered from J uly to September (Tukey HSD test: $P<0.05)$. In July, $K_{e}$ of females was significantly lower than that of nesting males (Tukey HSD test: $P<0 \cdot 05$ ). $N$ esting males had $K_{e}$ values in A pril that were significantly higher than those of females (Tukey HSD test: $P<0.01$ ) and female-like males (Tukey HSD test: $P<0.01$ ). Their $K_{e}$ values then decreased significantly to J uly (Tukey H SD test: $P<0.001$ ), A ugust (Tukey H SD test: $P<0.01$ ) and September (Tukey HSD test: $P<0.001$ ). $K_{e}$ variation in female-like males was not significant.

F rom the marking/recapture procedure, we were able to follow individual nesting males from $M$ arch to September. These data revealed that nesting males 


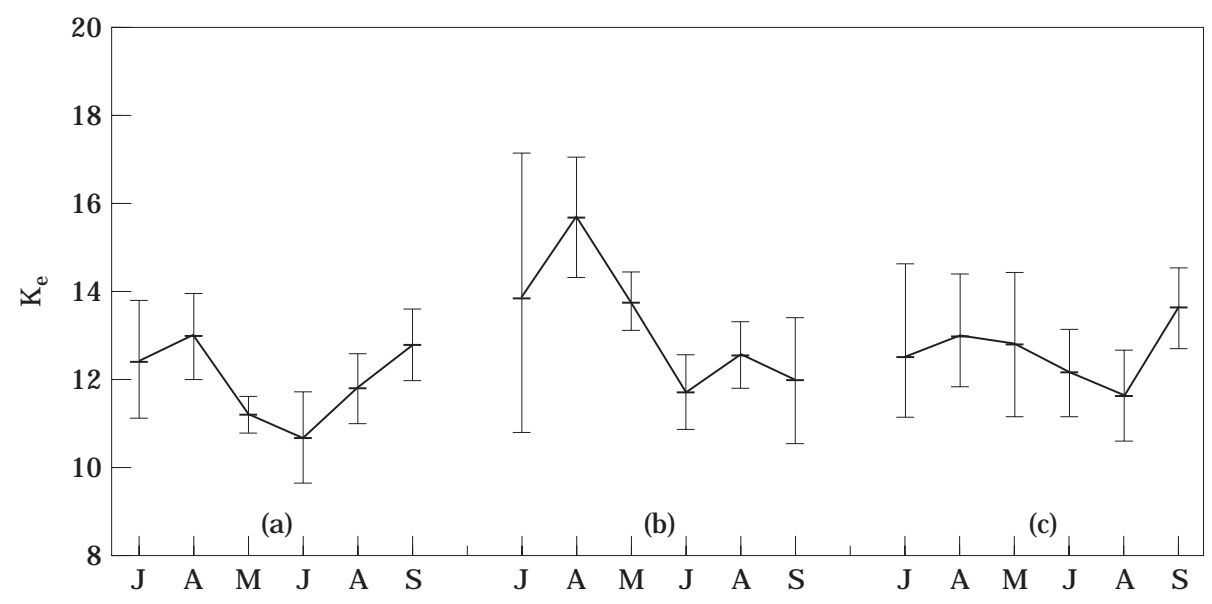

F IG. 3. Variation of mean ( \pm S.D.) eviscerated condition factors $\left(K_{e}\right)$ in $(a)$ females, (b) nesting males, and (c) female-like males throughout the year.

TABLE I. Two-way ANOVA results for the effects of month and sexual categories on the eviscerated condition factor $\left(K_{e}\right)$

\begin{tabular}{lrrrc}
\hline Effects & d.f. & M S & $F$ & $P$ \\
\hline M onth & 5 & 0.302 & 12.13 & 0.000001 \\
Sexual categories & 2 & 0.346 & 13.91 & 0.000004 \\
Interaction & 10 & 0.116 & 4.66 & 0.000014 \\
\hline
\end{tabular}

lost weight significantly from J une to J uly (W ilcoxon signed ranks test: $Z=2 \cdot 67$, $P<0.01, n=10$ ) and J uly to September (Wilcoxon signed ranks test: $Z=2 \cdot 20$, $P<0.05, n=6)$. This method failed in following females and female-like males since they were highly mobile (A Imada et al., 1994).

\section{FEEDING}

The highest values of the feeding index $\left(\mathrm{I}_{\mathrm{F}}\right)$ were reached prior to reproduction by nesting males $(4.55 \pm 1 \cdot 22$, range $=3 \cdot 35-6 \cdot 65, n=7$, in January) and by female-like males $(5 \cdot 06 \pm 1 \cdot 50$, range $=3 \cdot 40-7 \cdot 61, n=7$, in A pril), and in the beginning of the breeding season by females $(4 \cdot 54 \pm 1 \cdot 74$, range $=2 \cdot 92-7 \cdot 15, n=6$, in $\mathrm{M}$ ay) ( $\mathrm{F}$ ig. 4). There was a highly significant difference both between months and sexual categories (Table II). The females showed a slight increase in $I_{F}$ from J anuary to $M$ ay and the values stayed high during the breeding season. In nesting males, $I_{F}$ values decreased from January to A ugust. Their $I_{F}$ was significantly lower than that of female-like males in A pril (Tukey HSD test: $P<0.05$ ) and of females (Tukey H SD test: $P<0.05$ ) and female-like males (Tukey HSD test: $P<0.05)$ in J uly. The $I_{F}$ of nesting males decreased significantly from J anuary to $M$ ay (Tukey H SD test: $P<0.05$ ), July (Tukey H SD test: $P<0.001$ ) and A ugust (T ukey H SD test: $P<0.01$ ). $I_{F}$ variation in females and female-like males was not significant. 


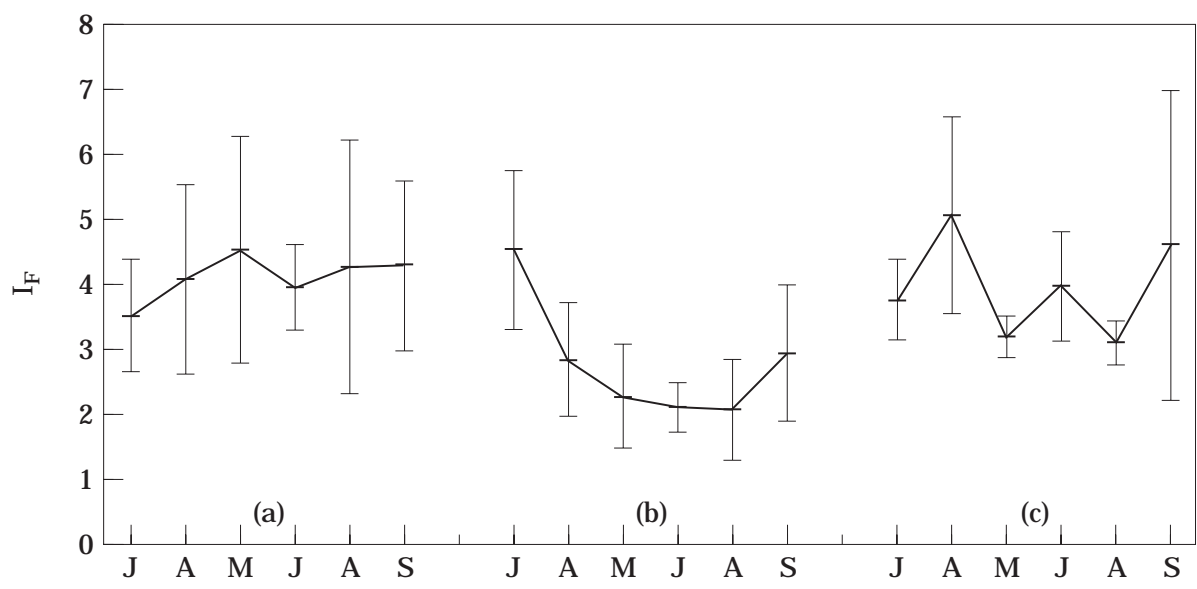

F IG. 4. Variation of mean ( \pm S.D.) feeding indices $\left(I_{F}\right)$ in $(a)$ females, (b) nesting males, and (c) female-like males throughout the year.

T ABLE II. T wo-way A N OVA results for the effects of month and sexual categories on the feeding index $\left(I_{F}\right)$

\begin{tabular}{lrrrc}
\hline Effects & d.f. & M S & $F$ & $P$ \\
\hline M onth & 5 & 2859 & 3.33 & 0.007686 \\
Sexual categories & 2 & 19449 & 22.66 & 0.000001 \\
Interaction & 10 & 3206 & 3.73 & 0.000242 \\
\hline
\end{tabular}

F emales also had significantly fewer empty guts while nesting males had more empty guts than expected by chance (T able III). A nother interesting feature was that $65 \%$ of the nesting males had blenniid eggs in their guts $(n=26)$, while only one female did $(n=27)$. In addition, females performed significantly more feeding acts per min (females, mean $=0.319$, s.D. $=0.283$, range $=0-0.846, n=16$; nesting males, mean $=0.017$, S.D. $=0.077$, range $=0-0.533, n=65 ; M$ ann-W hitney $U$-test: $Z=-6.28, P<0.001$ ), and significantly higher maximal displacements (females: mean $=564.3 \mathrm{~cm}, \quad$ s.D. $=503 \cdot 6$, range $=50-2000 \mathrm{~cm}, \mathrm{n}=14$; males: mean $=12.9 \mathrm{~cm}$, S.D. $=37 \cdot 2$, range $=0-200 \mathrm{~cm}, \mathrm{n}=65 ; M$ ann-W hitney $U$-test: $Z=6.23, P<0.001)$ than nesting males.

\section{FEMALE FECUNDITY}

The developmental time of 15 days given by Patzner \& Brandstätter (1988) was used to estimate the number of hatched eggs. This number was added to the total number of eggs in that inspection, resulting in the cumulative number of eggs laid in the interval considered (Table IV). It was assumed that most eggs were fertilized and that mortality prior to hatching could be ignored. The rate of eggs laid per female was calculated by subtracting the number of eggs from the first count from the total number of eggs laid and dividing by the number of days (30) and by the number of females (five). A mean daily rate of 162 eggs laid per 
T ABLE III. O ccurrence of empty guts on the different sexual categories on samples taken during the breeding season ( $M$ ay, J uly and A ugust) and statistical analysis using ACTU $S$

\begin{tabular}{lccc}
\hline & $\begin{array}{c}\text { N esting } \\
\text { males }\end{array}$ & $\begin{array}{c}\text { F emale-like } \\
\text { males }\end{array}$ & F emales \\
\hline Empty guts & 18 & 6 & 2 \\
Partially or completely full guts & 8 & 25 & 25 \\
Statistical analysis & & & \\
Simulated values<observed values: & 996 & 165 & $11^{*}$ \\
$\quad$ Empty guts & $3^{*}$ & 843 & 962 \\
$\quad$ Partially or completely full guts & $4^{*}$ & 906 & 998 \\
Observed values<simulated values: & 999 & 212 & 68 \\
$\quad$ Empty guts & & & \\
Partially or completely full guts & & & \\
\hline
\end{tabular}

$* \mathrm{P}<0.05$ (one-tailed).

$\chi^{2}=26 \cdot 78$, d.f. $=2, P<0.001$. F or details of ACTUS see Estabrook \& Estabrook (1989).

TABLE IV. Cumulative numbers of eggs present in each nest from the aquarium group: four nesting males, one floater male and five females

\begin{tabular}{|c|c|c|c|c|c|c|}
\hline \multirow{2}{*}{ D ay } & \multirow{2}{*}{ M ale 1} & \multirow{2}{*}{ M ale 2} & \multicolumn{2}{|c|}{$\mathrm{M}$ ale 3} & \multirow{2}{*}{$\mathrm{M}$ ale 4} & \multirow{2}{*}{ Total } \\
\hline & & & N est $A$ & N est $B$ & & \\
\hline 1 & 2118 & 219 & $?$ & & & 2337 \\
\hline 2 & 2426 & 490 & $?$ & & & 2916 \\
\hline 7 & 3966 & 2541 & $?$ & & & 6507 \\
\hline 12 & 5236 & 3773 & 4543 & & & 13552 \\
\hline 17 & 7431 & 4225 & 1155 & & & 12811 \\
\hline 23 & 9587 & 7123 & $*$ & 130 & 693 & 17533 \\
\hline 30 & 13861 & 9345 & $*$ & 616 & 2888 & 26710 \\
\hline
\end{tabular}

?, Presence of eggs could not be determined.

*Eggs were destroyed by the floater male.

female was obtained. The mean weight of each egg was $0.75 \mathrm{mg}(n=20)$. U sing the mean daily rate of 162 eggs and multiplying by 4 months (the duration of the breeding season), each female would lay an average of $14.6 \mathrm{~g}$ of eggs in each breeding season. The mean weight of the females in the low tide inspections in $J$ une and July (the peak of the breeding season) was $8.8 \mathrm{~g}(\mathrm{n}=20)$. If these calculations are realistic, total ovarian expenditure over the 4-month breeding season could be higher than somatic weight.

Patzner (1985), based on the frequency distribution of oocyte stages, determined that, in an Adriatic population of this species, fecundity $(F)$ showed a rectilinear relationship with body length expressed by the equation: $\mathrm{F}=125 \mathrm{~L}-5125$ (where $\mathrm{L}$ was the standard length in $\mathrm{mm}$ ). A pplying this formula to our data, the daily rate of eggs laid per female would be 82. This value is half that determined with direct egg counts. Our method may have overestimated the number of eggs if the females are overfed, or the method used 
by Patzner (1985) could have underestimated the number of eggs laid, if stage I and stage II oocytes would both develop in that breeding season. A third hypothesis is that female fecundity was much higher in our population. Either way, the weight in eggs laid by a female during the breeding season would be equal to or greater than her own body weight.

\section{DISCUSSION}

This paper shows that one major component of the costs of reproduction in nesting males is a reduction of feeding opportunities. Indeed, during the breeding season, nesting males showed a lower feeding index and feeding rate and, a higher proportion of empty stomachs than females. N esting males also lost weight, their $\mathrm{I}_{\mathrm{H}}$ declined, and their $\mathrm{K}_{\mathrm{e}}$ decreased significantly during the breeding season. In addition, they did not grow during this period. Such a deterioration in the condition of parental males had previously been reported in Lipophrys pholis (Linnaeus, 1758) (Qasim, 1957), Parablennius sanguinolentus (Valenciennes, 1836) (Santos \& A Imada, 1988; Santos, 1992; Santos et al., 1996), and other fish taxa with male parental care (e.g. M iller, 1984; Crivelli \& Britton, 1987). F or S. pavo, this reduced feeding is not a consequence of a suppression of the feeding motivation. Indeed, nesting males kept in aquaria will take food readily if it passes near the nest entrance (pers. obs.).

It seems likely that the nesting males engage in filial cannibalism as a means of diminishing their energy intake deficit. This behaviour has been described for several fish species with male parental care [e.g. Oxylebius pictus Gill by D eM artini (1987); Gasterosteus aculeatus L . by FitzG erald (1991); H ypsypops rubicundus ( $\mathrm{G}$ irard) by Sikkel (1994); see also FitzG erald (1992)]. A Ithough the eggs found in the guts of nesting males might represent dead embryos removed as part of the male's parental activities, we noted that some embryos showed no sign of damage.

It is suggested that this reduced feeding is caused or enhanced by the dense nest aggregations found in this population, and by the constant pressure exerted by non-nesting males, both floaters and sneakers (A Imada et al., 1994, 1995; $\mathrm{G}$ onçalves et al., 1996). In fact, nesting males do not defend food reserves, and leave their nests infrequently (Gonçalves \& Almada, 1997) and for short distances (as shown by the small maximal displacements). This behaviour makes sense if one considers that the nests are cavities with narrow entrances that are much easier to defend for a male that is inside. $W$ ith the high pressure of floaters and sneakers, a male that leaves the nest frequently, would face the risk of having to dislodge an intruder, that would have the advantage of being inside the nest.

The presence of dense nest aggregations and the excess of males without nests may also explain the differences between our results and those of Podroschko et al. (1985). These authors found that $I_{H}$ did not deteriorate during the breeding season in males of an Adriatic population of S. pavo, who defended small territories around the nest (Patzner et al., 1986). However, such a comparison is made more difficult by the fact that these authors collected their fishes with baited traps, which could have biased the samples in favour of males that were feeding actively. 
It is also important to note that this reduction of feeding by the nesting males was not a mere consequence of a shortage of food in the area. N on-nesting males and especially females kept feeding actively during the breeding season, and the available evidence suggests that this high level of feeding was responsible for the large number of eggs produced by the females throughout the season. D espite their high level of egg production, the $I_{H}$ of females was not reduced during the breeding season, and their $\mathrm{K}_{e^{\prime}}$ although depressed in the peak of the breeding season, was quicker to recover than that of males.

$F$ inally, the data suggest that the female-like males incurred lower reproductive costs, at least in terms of energy. The $I_{G}$ values also suggest that, for these males, the breeding season may have been shorter, but more data are needed to test this hypothesis. These males were smaller and younger than the nesting males (Gonçalves et al., 1996) and it is likely that their reproductive biology reflects a compromise between the need to try to fertilize some eggs, and the need to grow, becoming able to secure nests and act as parental males.

This study is part of a project supported financially by J unta $\mathrm{N}$ acional de Investigação Científica e Tecnológica (J N ICT-PBIC/1313/M A R/92). E.G. was also supported by a grant from J N ICT (BD/872/90-IG). The authors thank the staff of Parque $\mathrm{N}$ atural da $\mathrm{R}$ ia F ormosa for their valuable help during the field work, and especially Director N. L ecoq for institutional support. We also thank $P$. R é and L aboratório M arítimo da $G$ uia for support, A. J. dos Santos, R. Oliveira and E. R odrigues, who helped in the field work, and $\mathrm{J}$. Thorpe and an anonymous referee for their valuable comments on the manuscript.

\section{R eferences}

Almada, V. C. (1990). Etologia da Reprodução e Cuidados Parentais nos Peixes Ósseos-Contributos para uma A nálise Filogenética e Ecológica. PhD thesis, $U$ niversity of $\mathrm{L}$ isbon.

A Imada, V. C. \& Santos, R. S. (1995). Parental care in the rocky littoral: adaptation and exaptation in A tlantic and $M$ editerranean blennies. R eviews in $\mathrm{F}$ ish Biology and Fisheries 5, 23-37.

A Imada, V. C., Gonçalves, E. J., Oliveira, R. F. \& Barata, E. N. (1992). Some features of the territories in the breeding males of the intertidal blenny Lipophrys pholis (Pisces: Blenniidae). J ournal of the $M$ arine Biological Association of the U nited Kingdom 72, 187-197.

Almada, V. C., Gonçalves, E. J., Santos, A. J. \& Baptista, M. C. (1994). Breeding ecology and nest aggregations in a population of Salaria pavo (Pisces: Blenniidae) in an area where nest sites are very scarce. J ournal of Fish Biology 45, 819-830.

Almada, V. C., Gonçalves, E. J., Oliveira, R. F. \& Santos, A. J. (1995). Courting females: ecological constraints affect sex roles in a natural population of the blenniid fish Salaria pavo. Animal Behaviour 49, 1125-1127.

Barlow, G . W . (1984). Patterns of monogamy among teleost fishes. A rchiv für Fischerei W issenschaft 35, 75-123.

Baylis, J. R. (1981). The evolution of parental care in fishes, with reference to Darwin's rule of male sexual selection. Environmental Biology of Fishes 6, 223-251.

Blumer, L. S. (1979). M ale parental care in the bony fishes. Quarterly R eview of Biology 54, 149-161.

Chellappa, S., H untingford, F. A., Strang, R. H . C. \& Thomson, R. Y . (1989). A nnual variation in energy reserves in male three-spined stickleback, Gasterosteus aculeatus L. (Pisces, G asterosteidae). J ournal of Fish B iology 35, 275-286.

Crivelli, A. J. \& B ritton, R. H. (1987). Life history adaptations of Gasterosteus aculeatus in a M editerranean wetland. Environmental Biology of Fishes 18, 109-125. 
D eM artini, E. E . (1987). Paternal defence, cannibalism and polygamy: factors influencing the reproductive success of painted greenling (Pisces: Hexagrammidae). A nimal Behaviour 35, 1145-1158.

Estabrook, C. B. \& Estabrook, G. F. (1989). A CTU S: a solution to the problem of small samples in the analysis of two-way contingency tables. H istorical M ethods 22, 5-8.

FitzG erald, G. J. (1991). The role of cannibalism in the reproductive ecology of the threespine stickleback. Ethology 89, 177-194.

FitzG erald, G . J . (1992). Filial cannibalism in fishes: why do parents eat their offspring? Trends in Ecology and Evolution 7, 7-10.

Gittleman, J. L. (1981). The phylogeny of parental care in fishes. A nimal Behaviour 29, 936-941.

Gonçalves, E. J. \& Almada, V. C. (1997). A comparative study of territoriality in intertidal and subtidal blennioids (Teleostei, Blennioidei). Environmental Biology of Fishes, in press.

G onçalves, E. J ., A Imada, V. C., Oliveira, R . F . \& Santos, A . J . (1996). F emale mimicry as a mating tactic in males of the blenniid fish Salaria pavo. J ournal of the $M$ arine Biological A ssociation of the U nited Kingdom 76, 529-538.

ICN (1993). L ivro V ermelho dos V ertebrados de Portugal, Vol. III-P eixes M arinhos e Estuarinos. Lisboa: ICN .

M iller, P. J. (1984). The tokology of gobioid fishes. In Fish Reproduction: Strategies and Tactics (Potts, G. W. \& W ootton, R. J., eds), pp. 119-154. L ondon: A cademic Press.

Patzner, R. A . (1985). The reproduction of Blennius pavo (Teleostei, Blenniidae). III. F ecundity. Z oologischer A nzeiger 214, 1-6.

Patzner, R . A . \& Brandstätter, R . (1988). R earing of B lennius pavo R isso, 1810. B ulletin de l'I nstitut océanographique, $M$ onaco 5, 223-226.

Patzner, R. A., Seiwald, M., A dlgasser, M . \& K aurin, G . (1986). The reproduction of Blennius pavo. $V$. R eproductive behaviour in natural environment. Z oologischer A nzeiger 216, 338-350.

Podroschko, S., Patzner, R. A . \& A dam, H. (1985). The reproduction of Blennius pavo (Teleostei, Blenniidae). IV. Seasonal variation in $\mathrm{HSI}$, the liver glycogen value and histological aspects of the liver. Z oologischer A nzeiger 215, 265-273.

Q asim, S. Z. (1957). The biology of Blennius pholis L. (Teleostei). Proceedings of the Z oological Society of L ondon 128, 161-206.

Santos, R. S. (1992). Behavioural Ecology, Phenology and Ethology of an Intertidal Blenny Parablennius sanguinolentus parvicornis (Valenciennes in Cuvier \& Valenciennes 1836) (Pisces: Blenniidae), from the A zores. PhD thesis, U niversity of Liverpool.

Santos, R. S. \& A Imada, V. C. (1988). Intraspecific variations in reproductive tactics in males of the rocky intertidal fish Blennius sanguinolentus in the Azores. In Behavioral Adaptation to Intertidal L ife (Chelazzi, G. \& Vannini, M., eds), pp. 421-447. $\mathrm{N}$ ew $\mathrm{Y}$ ork: Plenum Press.

Santos, R. S., H awkins, S. J . \& N ash, R. D. M . (1996). R eproductive phenology of the A zorean rock pool blenny a fish with alternative mating tactics. J ournal of $F$ ish Biology 48, 842-858.

Sargent, R. C. \& G ross, M . R . (1986). Williams' principle: an explanation of parental care in teleost fishes. In The Behaviour of T eleost Fishes (Pitcher, T. J., ed.), pp. 275-293. London: Croom Helm.

Sikkel, P. C. (1994). F ilial cannibalism in a parent-caring marine fish: the influence of egg developmental stage and position in the nest. A nimal B ehaviour 47, 1149-1158.

Smith, C. \& W ootton, R. J. (1995). The costs of parental care in teleost fishes. R eviews in Fish Biology and Fisheries 5, 7-22.

Sokal, R . R . \& R ohlf, F. J . (1981). B iometry-The Principles and P ractice of Statistics in Biological Research, 2nd edn. N ew Y ork: W. H. F reeman.

W ootton, R. J. (1973). The effect of size of food ration on egg production in the female three-spined stickleback Gasterosteus aculeatus L. J ournal of Fish Biology 5, 89-96. 